\title{
Video Article \\ Use of Recombinant Fusion Proteins in a Fluorescent Protease Assay Platform and Their In-gel Renaturation
}

\author{
Beáta Bozóki ${ }^{* 1,2}$, János András Mótyán ${ }^{1}$, Márió Miczi ${ }^{1}$, Lívia Diána Gazda ${ }^{1}$, József Tőzsér ${ }^{1}$ \\ ${ }^{1}$ Department of Biochemistry and Molecular Biology, Faculty of Medicine, University of Debrecen \\ ${ }^{2}$ Biotechnology Research Department, Gedeon Richter Plc \\ * These authors contributed equally
}

Correspondence to: József Tőzsér at tozser@med.unideb.hu

URL: https://www.jove.com/video/58824

DOI: doi:10.3791/58824

Keywords: Biochemistry, Issue 143, recombinant fusion protein substrate, protease assay, Ni-NTA magnetic agarose beads, fluorescent protein, ingel renaturation, human immunodeficiency virus type 1 protease

Date Published: 1/16/2019

Citation: Bozóki, B., Mótyán, J.A., Miczi, M., Gazda, L.D., Tőzsér, J. Use of Recombinant Fusion Proteins in a Fluorescent Protease Assay Platform and Their In-gel Renaturation. J. Vis. Exp. (143), e58824, doi:10.3791/58824 (2019).

\section{Abstract}

Proteases are intensively studied enzymes due to their essential roles in several biological pathways of living organisms and in pathogenesis; therefore, they are important drug targets. We have developed a magnetic-agarose-bead-based assay platform for the investigation of proteolytic activity, which is based on the use of recombinant fusion protein substrates. In order to demonstrate the use of this assay system, a protocol is presented on the example of human immunodeficiency virus type 1 (HIV-1) protease. The introduced assay platform can be utilized efficiently in the biochemical characterization of proteases, including enzyme activity measurements in mutagenesis, kinetic, inhibition, or specificity studies, and it may be suitable for high-throughput substrate screening or may be adapted to other proteolytic enzymes.

In this assay system, the applied substrates contain $\mathrm{N}$-terminal hexahistidine (His ${ }_{6}$ ) and maltose-binding protein (MBP) tags, cleavage sites for tobacco etch virus (TEV) and HIV-1 proteases, and a C-terminal fluorescent protein. The substrates can be efficiently produced in Escherichia coli cells and easily purified using nickel (Ni)-chelate-coated beads. During the assay, the proteolytic cleavage of bead-attached substrates leads to the release of fluorescent cleavage fragments, which can be measured by fluorimetry. Additionally, cleavage reactions can be analyzed by sodium dodecyl sulfate-polyacrylamide gel electrophoresis (SDS-PAGE). A protocol for the in-gel renaturation of assay components is also described, as partial renaturation of fluorescent proteins enables their detection based on molecular weight and fluorescence.

\section{Video Link}

The video component of this article can be found at https://www.jove.com/video/58824/

\section{Introduction}

Proteolytic enzymes belong to the most intensively investigated enzyme groups due to their importance in metabolic pathways and in industrial applications, as well. Their key role in viral diseases, the regulation of blood clotting, cancer, and cardiovascular and neurodegenerative diseases makes proteases prominent targets in the field of drug discovery. Therefore, the detailed characterization of substrate specificity and inhibitor profiling of the protease (PR) of interest is pivotal and is preferably performed by rapid, cost-efficient, and robust biochemical assays $\mathbf{s}^{1,2,3}$.

Nowadays, the vast majority of in vitro protease assays applied in the field of drug discovery for compound profiling are homogeneous, fluorescent peptide-based, and high-throughput screening (HTS)-compatible platforms ${ }^{4}$. Moreover, labeled peptides are not only suitable for library screening, but they also offer great tools for the determination of enzyme kinetic parameters on the selected substrates. In other cases, where labeling of the substrate is not possible, separation-based assays may provide a possible solution to assess the kinetic properties of proteolytic reactions ${ }^{3}$.

Generally, in vitro protease assays are based on the use of two types of substrate: short peptides or whole proteins. In those cases, where the cleavage of short peptide sequences reflect the cleavage properties sufficiently, the following standard approaches are applicable: (i) examining standard protein substrates such as oxidized insulin B-chain, (ii) testing commercially available substrates of other proteases, (iii) screening synthetic and fluorescently labeled peptide libraries created by combinatorial chemistry, or (iv) using genetic methods, for instance, biological display technologies ${ }^{5,6}$. Besides the conventional classification, other novel platforms are also available for substrate generation (e.g., the formation of proteome-derived peptide libraries ${ }^{7}$ or special subtypes of genetic methods, like the recombinant fusion protein-based substrates $8,9,10,11,12$.

All of the above-mentioned substrate types and assays have their own advantages and limitations, and the development of assay formats combining and/or improving the advantages of the known platforms is still in demand. Here we describe a protocol for a separation-based fluorescent protease assay, which utilizes recombinant substrates. These fusion proteins consist of His ${ }_{6}$ and MBP tags fused to a control cleavage site of TEV PR, which is followed by the substrate sequence of interest that is directly connected to a C-terminal fluorescent protein 
(FP) (Figure 1A). The cloning of a DNA sequence coding for a cleavage site of interest into the 'cloning cassette' can be performed by a single ligation reaction into the expression plasmid, which has been linearized previously by restriction endonucleases.

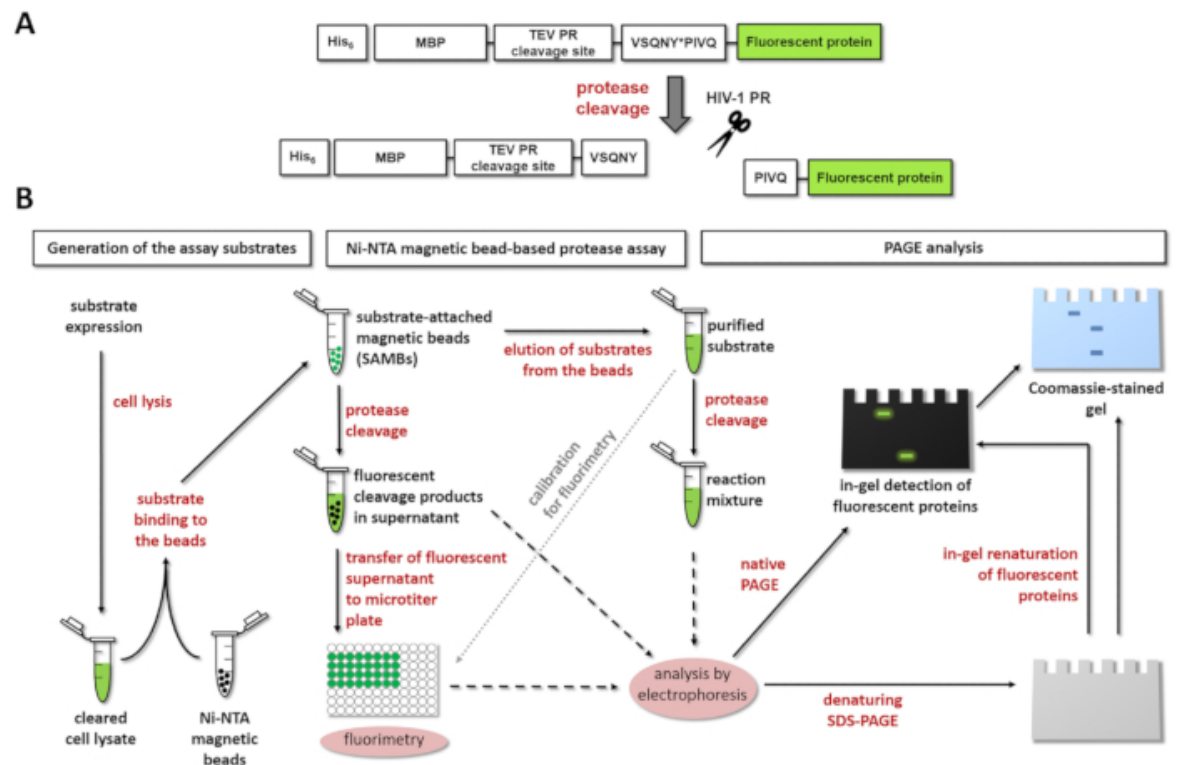

Figure 1: Principle of the fluorescent protease assay. (A) The schematic representation of a fluorescent substrate and its cleavage by human immunodeficiency virus type 1 (HIV-1) protease is shown. The arrow indicates the cleavage position within the matrix/capsid cleavage site sequence of HIV-1 protease (VSQNY*PIVQ). (B) The fluorescent substrates can be used to analyze enzyme reactions by the Ni-NTA magneticbead-based assay and by polyacrylamide gel electrophoresis, as well, as is shown in the workflow diagram. Please click here to view a larger version of this figure.

Although proteolytic assays using similar recombinant protein substrates-containing an affinity tag, a proteolytic cleavage site, and a fluorescent protein-have already been described ${ }^{8,9,10}$, the system presented here intends to integrate and improve on the advantages of these methods. An important difference is that the fusion protein substrates in this assay platform are equipped with MBP to enhance protein solubility ${ }^{13}$ and contain a control cleavage site for TEV PRs. Furthermore, the substrates contain new generation fluorescent proteins, which are highly stable and have a monomeric form to prevent substrate aggregation. Besides the previously published application of mTurquoise2-and mApple-fused forms ${ }^{14}$, here we also show results given by the use of a recombinant substrate containing a monomeric enhanced yellow fluorescent protein (mEYFP) fluorescent tag. Hereby we demonstrate the compatibility of the system with other fluorescent proteins and represent some general types of results that can be acquired by the protease assay.

The recombinant fusion proteins are expressed in E. coli BL21(DE3) cells and are used as substrates for the assay in a nickel-nitrilotriacetic acid (Ni-NTA)-coated magnetic-agarose-bead-attached form. The C-terminal cleavage products are liberated from the bead surface into the supernatant upon cleavage by the protease of interest. After the separation of the supernatant (containing the enzyme and the cleavage products) from the magnetic beads, the fluorescence can be measured to determine the cleavage properties of the enzyme. In contrast to the previously described methods, in the system presented here, the amounts of substrate and C-terminal cleavage products are uniquely quantified based on a detailed substrate calibration procedure. The assay system can be supported by an SDS-PAGE analysis of the assay samples; a subsequent fluorescent in-gel visualization may be applied immediately after the electrophoresis or after the in-gel renaturation of the nondenatured and denatured fluorescent components, respectively ${ }^{14}$.

The flexibility and structure of the 'cloning cassette' allow a time- and cost-efficient insertion of a wide variety of sequences into the construct and, thus, promotes the generation of substrate libraries. Since all assay steps are automation- and HTS-compatible, the system can be especially attractive for, for instance, protease specificity measurements and mutagenesis studies, or it may also be effectively utilized for industrial protease inhibitor screening and/or antiviral drug development, as well.

Enzyme kinetic parameters $\left(k_{\mathrm{cat}}, K_{\mathrm{m}}\right)$ can be determined by the developed separation-based assay; therefore, it may be suitable to perform individual enzyme kinetic measurements, such as the time-course, substrate-dependent, and inhibition studies. This proves that the recombinant fusion protein substrates provide good alternatives for the frequently utilized synthetic oligopeptide substrates, and due to their high similarity to the polyprotein substrates, they represent the naturally occurring enzyme-substrate interactions more accurately.

\section{Protocol}

\section{Generation of the substrate-coding expression plasmids}

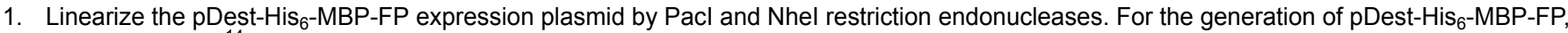
see Bozóki et al. ${ }^{14}$.

1. Add 1,500-2,000 $\mu \mathrm{g}$ of pDest-His ${ }_{6}-\mathrm{MBP}-\mathrm{FP}$ expression plasmid, $2 \mu \mathrm{L}$ each of Pacl and Nhel restriction endonucleases, $10 \mu \mathrm{L}$ of $10 \mathrm{x}$ buffer (see Table of Materials), and nuclease-free water (NFW) to $100 \mu \mathrm{L}$ in a microcentrifuge tube. 
2. Incubate the reaction mixture at $37^{\circ} \mathrm{C}$ for $1 \mathrm{~h}$.

2. Add $20 \mu \mathrm{L}$ of $6 \mathrm{x}$ DNA purple loading dye to the reaction mixture and separate the cleavage products by electrophoresis, using $1 \%$ agarose gel. Apply a $1 \mathrm{kB}$ DNA ladder as standard.

3. Rinse the gel for $15 \mathrm{~min}$ in $20 \mathrm{~mL}$ of TAE buffer ( $40 \mathrm{mM}$ Tris, $20 \mathrm{mM}$ acetic acid, $1 \mathrm{mM}$ EDTA, pH 8.5) containing $20 \mu \mathrm{L}$ of SYBR green solution and excise the band of the linearized plasmid out of the agarose gel, using a sharp tool.

NOTE: While illuminating the gel by a dark-reading blue transilluminator (DRBT), the linearized pDest-His ${ }_{6}-\mathrm{MBP}_{\mathrm{FP}}$ plasmid appears as a discrete and bright band at around 7-8 kB.

4. Purify the linearized expression plasmid from the gel slice by using a gel extraction kit according to the manufacturer's instructions.

5. Insert the substrate sequence into the linearized pDest-His 6 -MBP-FP expression plasmid.

1. Anneal the forward (FWD) and the reverse (REV) E. coli codon-optimized oligonucleotide primers coding for the substrate sequence of interest.

NOTE: The annealed primers will be flanked by the cohesive ends corresponding to Pacl and Nhel restriction endonuclease cleavage sites (Figure 2).

1. Mix $150 \mathrm{ng}$ of linearized expression plasmid with $200 \mathrm{ng}$ of FWD and $200 \mathrm{ng}$ of REV oligonucleotide primers in a $0.2 \mathrm{~mL}$ polymerase chain reaction (PCR) tube and adjust the volume to $17 \mu \mathrm{L}$ by adding NFW.

2. Incubate the mixture at $65^{\circ} \mathrm{C}$ for $2 \mathrm{~min}$ and, then, at $4{ }^{\circ} \mathrm{C}$ for at least $2 \mathrm{~min}$.

2. Perform the insertion of the annealed primers into the linearized plasmid by ligation.

1. Add $2 \mu \mathrm{L}$ of T4 ligase buffer (10x) and $1 \mu \mathrm{L}$ of T4 ligase to the mixture containing the linearized plasmid and the annealed primers.

2. Incubate the ligation mixture at $16{ }^{\circ} \mathrm{C}$ for $16 \mathrm{~h}$.

\begin{tabular}{l|l|ccccccccc|c|}
\hline Pacl & V & S & Q & N & Y & P & I & V & Q & Nhel \\
\hline FWD primer: 5'
\end{tabular}

Figure 2: Oligonucleotide primers coding for a proteolytic cleavage site sequence. Forward and reverse primers encode the VSQNY*PIVQ cleavage site sequence of HIV-1 PR. After annealing the complementary oligonucleotide primers, the short double-stranded DNA contains sticky ends, corresponding to that of Pacl and Nhel restriction endonucleases. Please click here to view a larger version of this figure.

6. Transform $100 \mu \mathrm{L}$ of BL21(DE3) competent cells by $5 \mu \mathrm{L}$ of ligation mixture and spread the cells on lysogeny broth (LB) agar plates containing ampicillin.

NOTE: The fluorescent proteins will be in the same open reading frame with the N-terminal fusion tags only after a successful ligation. A few days after transformation, the colonies (containing the expression plasmid coding for the inserted cleavage site of interest) will show visible fluorescence with or even without using a DRBT.

7. Prepare glycerol stock from the depicted colonies.

1. Wash a discrete colony into a $50 \mathrm{~mL}$ centrifuge tube containing $5 \mu \mathrm{L}$ of LB medium containing ampicillin (at a final concentration of 100 $\mu \mathrm{g} / \mathrm{mL})$.

2. Incubate it at $37^{\circ} \mathrm{C}$ for $8 \mathrm{~h}$ while continuously shaking at $220 \mathrm{rpm}$; then, harvest the cells by centrifugation at $1,000 \times \mathrm{g}$ for $5 \mathrm{~min}$ at room temperature.

3. Gently suspend the cells in $1 \mathrm{~mL}$ of $80 \%$ glycerol solution (diluted with distilled water) and add $500 \mu \mathrm{L}$ of $10 \mathrm{mM} \mathrm{MgCl}_{2}$ solution to the suspension.

4. Transfer the suspension to a freezing tube and store the stocks at $-70^{\circ} \mathrm{C}$.

8. Verify the sequence of the generated plasmid by DNA sequencing.

1. Add $10 \mu \mathrm{L}$ of the glycerol stock (prepared in step 1.7) to $5 \mathrm{~mL}$ of LB medium containing $100 \mu \mathrm{g} / \mathrm{mL}$ ampicillin in a $50 \mathrm{~mL}$ centrifuge tube.

2. Incubate the suspension at $37^{\circ} \mathrm{C}$ for $16 \mathrm{~h}$ while continuously shaking at $220 \mathrm{rpm}$; then, harvest the cells by centrifugation at $2,000 \times \mathrm{g}$ for 10 min at $4{ }^{\circ} \mathrm{C}$.

3. Isolate the expression plasmid from the cell pellet by a plasmid miniprep kit (see Table of Materials) according to the manufacturer's instructions, and use the purified plasmid for DNA sequencing.

NOTE: For sequencing, 5'-GATGAAGCCCTGAAAGACGCGCAG-3' (forward) and 5'-

GCAAGGCGATTAAGTTGGGTAACGC-3' (reverse) oligonucleotide primers may be used.

\section{Expression of the fluorescent substrates}

1. Prepare the starter culture.

1. Add $10 \mu \mathrm{L}$ of the glycerol stock (prepared in step 1.7) to $5 \mathrm{~mL}$ of LB medium containing $100 \mu \mathrm{g} / \mathrm{mL}$ ampicillin in a $50 \mathrm{~mL}$ centrifuge tube.

2. Incubate the suspension at $37^{\circ} \mathrm{C}$ for $15 \mathrm{~h}$ while continuously shaking at $220 \mathrm{rpm}$.

2. Transfer the bacterial culture $(5 \mathrm{~mL})$ to $50 \mathrm{~mL}$ of fresh LB medium containing $100 \mu \mathrm{g} / \mathrm{mL}$ ampicillin in a $500 \mathrm{~mL}$ sterile Erlenmeyer flask.

3. Grow the cells at $37^{\circ} \mathrm{C}$ to an absorbance of $0.6-0.8$ at a $600 \mathrm{~nm}$ wavelength, while continuously shaking at $220 \mathrm{rpm}$.

NOTE: If a tetracycline treatment is to be applied at step 2.5, it is not recommended to grow the cells to an absorbance of more than 0.6 at $600 \mathrm{~nm}$. 
4. Add isopropyl $\beta$-D-1-thiogalactopyranoside (IPTG) to the $1 \mathrm{mM}$ final concentration to induce protein expression.

5. If a tetracycline treatment is NOT applied, incubate the culture for $3 \mathrm{~h}$ at $37^{\circ} \mathrm{C}$ while continuously shaking at $220 \mathrm{rpm}$ and continue the protocol with step 2.6. If a tetracycline treatment is applied, continue the protocol with steps 2.5.1-2.5.3.

NOTE: Some FPs produced by E. coli cells may have a longer maturation time (see previous work) ${ }^{16,17}$; in these cases, the protein translation can be optionally arrested by the tetracycline treatment, in order to increase the fluorescent yield of the substrate solution.

1. Incubate the cell suspension for $2 \mathrm{~h}$ at $37^{\circ} \mathrm{C}$ while continuously shaking at $220 \mathrm{rpm}$; then, add a tetracycline solution (at a final concentration of $200 \mu \mathrm{g} / \mathrm{mL}$ ).

2. Incubate the cell culture according to the maturation time of the fluorescent protein of choice at $37^{\circ} \mathrm{C}$, while continuously shaking at $220 \mathrm{rpm}$.

6. Transfer $2 \times 25 \mathrm{~mL}$ of the culture to clean $50 \mathrm{~mL}$ centrifuge tubes and harvest the cells by centrifugation at $4,000 \times g$ for $15 \mathrm{~min}$ at $4{ }^{\circ} \mathrm{C}$

7. Discard the supernatant and store the bacterial cell pellets at $-70^{\circ} \mathrm{C}$ for at least $1 \mathrm{~h}$. NOTE: Cells containing the expressed fluorescent substrates show visible fluorescence with or even without using a DRBT.

\section{Cell disruption}

1. Place the frozen cell pellet on ice and let it thaw for $15 \mathrm{~min}$.

2. Add $2 \mathrm{~mL}$ of lysis buffer $\left(50 \mathrm{mM} \mathrm{NaH}_{2} \mathrm{PO}_{4}, 300 \mathrm{mM} \mathrm{NaCl}, 10 \mathrm{mM}\right.$ imidazole, $0.05 \%$ Tween 20 , pH 8$)$ to the pellet and suspend the cells.

3. Add $10 \mu \mathrm{L}$ of freshly prepared phenylmethanesulfonyl-fluoride (PMSF) protease inhibitor solution (8.7 $\mathrm{mg} / \mathrm{mL}$, dissolved in ethanol) to the suspension.

4. Add $2 \mathrm{mg}$ of lysozyme and 20 units of DNase to the suspension and suspend it.

5. Incubate the suspension on ice for $15 \mathrm{~min}$, and vortex it occasionally.

6. Transfer $2 \times 1 \mathrm{~mL}$ of the suspension to $1.5 \mathrm{~mL}$ microcentrifuge tubes and sonicate the suspensions for $3 \mathrm{~min}$, in rounds of $10 \mathrm{~s}$ of sonication and $5 \mathrm{~s}$ of resting.

7. Centrifuge the tubes at $10,000 \times g$ for $20 \mathrm{~min}$ at room temperature; then, remove the fluorescent supernatant (cleared bacterial cell lysate) carefully from each tube and transfer it to new microcentrifuge tubes.

NOTE: Cleared lysates containing the fluorescent substrate show visible fluorescence with or even without using a DRBT and can be stored at $4{ }^{\circ} \mathrm{C}$ for up to 2 weeks. Do NOT freeze it. Cleared lysates can be utilized directly for sample preparation in the protease assay (see section 4.1) or also can be used for substrate purification (see step 4.5.1).

\section{Ni-NTA magnetic-bead-based protease assay}

NOTE: Due to the flexibility of the assay platform, it can be optimized to many different types of studies. For this reason and due to the difference in the activity rate of the enzymes of choice, some of the assay parameters (where it is denoted) cannot be explicitly described but need to be optimized to the individual aims and experimental design. As a guidance, parameters of some types of studies are denoted at the particular steps.

\section{Sample preparation}

1. Generation of substrate-attached magnetic beads

1. Place a closed $2 \mathrm{~mL}$ low-protein-binding (see Table of Materials) microcentrifuge tube containing new or recycled (see section 4.7) Ni-NTA magnetic agarose beads in a magnetic particle concentrator (MPC).

NOTE: The amount of the applied bead suspension is to be set based on the experimental design. We used $1 \mathrm{~mL}$ of magnetic bead solution $(5 \%, v / v)$ at each experiment.

2. Beads may stick to the wall and/or into the lid of the microcentrifuge tube; therefore, turn the MPC upside-down in every direction to make sure that all of the beads are collected.

3. Remove the supernatant and discard it.

4. Wash the beads by lysis buffer.

1. Add $1.8 \mathrm{~mL}$ of lysis buffer to the beads and remove the closed tube from the MPC.

2. Suspend the beads in the tube by shaking and/or turning the tubes upside-down until the sample is completely homogeneous.

3. Place the tube back into the MPC and turn it upside-down to collect the beads.

4. Open the tube and discard the supernatant.

5. Add $1.0-1.8 \mathrm{~mL}$ of the cleared lysate (prepared in step 3.7) to the beads and remove the tube from the MPC.

6. Turn the closed tube upside-down until the beads are completely homogeneous and slowly rotate the tube by a rotator at room temperature for $30 \mathrm{~min}$.

7. Place it into the MPC and remove the cleared cell lysate from the beads and from the lid. NOTE: The cleared cell lysate may be discarded or saved for further use (see the note after step 3.7).

8. Add $1 \%$ Tween $20(\mathrm{pH} 7)$ to the substrate-attached magnetic beads (SAMBs). NOTE: SAMBs show visible fluorescence with or even without using a DRBT.

\section{Washing of the SAMBs}

1. Place the tube with the SAMB suspension into the MPC and discard the supernatant.

2. Wash the SAMBs $3 x$ with each buffer: i) $1.8 \mathrm{~mL}$ of $1 \%$ Tween $20(\mathrm{pH} 7)$; ii) $1.8 \mathrm{~mL}$ of washing buffer $\left(50 \mathrm{mM} \mathrm{NaH}_{2} \mathrm{PO}_{4}, 300 \mathrm{mM}\right.$ $\mathrm{NaCl}, 5 \mathrm{mM}$ imidazole, $0.05 \%$ Tween 20, pH 7); iii) $1.8 \mathrm{~mL}$ of cleavage buffer (50 mM NaH $\mathrm{PO}_{4}, 300 \mathrm{mM} \mathrm{NaCl}, 0.05 \% \mathrm{Tween} 20$, $\mathrm{pH} 7$ ).

NOTE: For the washing procedure, see step 4.1.1.4. The cleavage buffer may be changed according to the experimental needs, but it is recommended to check the manual of the Ni-NTA magnetic beads to determine compatibility. 
3. Preparation of the SAMB stock solution

1. Add a cleavage buffer to the washed SAMBs to create a SAMB stock solution. NOTE: After the addition of the buffer, DO NOT shake or turn the tube upside-down. The volume of the cleavage buffer depends on the individual experimental design and must be calculated based on the number of magnetic beads (see step 4.1.1.1) and on the volumes to be used in step 4.1.4.2. For $2 \mathrm{~mL}$ tubes, the applied volume is up to 1,900 $\mu \mathrm{L}$ (see Table 1). The recommended magnetic bead density of the SAMB stock solution is $2 \%-10 \%(\mathrm{v} / \mathrm{v})$.

\begin{tabular}{|l|l|}
\hline Study type & Volume of cleavage buffer $(\boldsymbol{\mu L})$ \\
\hline S-dependent measurements (Fig 4) & 1600 \\
\hline Time-course measurements (Fig 5A) & 1600 \\
\hline Inhibition study (Fig 5B) & 1900 \\
\hline pH dependence study (Fig 6) & 1400 \\
\hline
\end{tabular}

Table 1: Volume of the cleavage buffer used to prepare the SAMB stock solution in the different types of measurements.

2. Remove the closed tube from the MPC. Use the SAMB stock solution immediately or store it at $4{ }^{\circ} \mathrm{C}$ for up to $24 \mathrm{~h}$.

4. Generation of the assay samples using the SAMB stock solution

NOTE: The details of this part of the assay are strongly dependent on the individual experimental design (sample types are shown in Table 2).

\begin{tabular}{|l|l|}
\hline Sample type & Notes \\
\hline Reaction sample (R) & $\begin{array}{l}\text { - used for assessing cleavage properties } \\
\text { - contains both the enzyme and the substrate in } \\
\text { cleavage buffer }\end{array}$ \\
\hline Substrate blank sample (B) & $\begin{array}{l}\text { - used for assessing spontaneous substrate } \\
\text { dissociation (see Step 4.6.2) } \\
\text { - contains only the substrate in cleavage buffer }\end{array}$ \\
\hline Substrate control sample (C) & $\begin{array}{l}\text { - for detemining substrate concentration (see Step } \\
\text { - contains only the substrate in elution buffer }\end{array}$ \\
\hline
\end{tabular}

Table 2: Sample types of the Ni-NTA magnetic-bead-based protease assay.

1. Prepare $2 \mathrm{~mL}$ of low-protein-binding microcentrifuge tubes for the assay samples.

NOTE: Other low protein binding plastic wares may also be used. Use round- or flat-bottom tubes to ensure the free movement of SAMBs. See the recommended number of tubes in Table 3.

\begin{tabular}{|l|l|l|c|}
\hline Study type & R & B & C \\
\hline $\begin{array}{l}\text { S-dependent measurements } \\
\text { (Fig 4) }\end{array}$ & 5 & 5 & 2 \\
\hline $\begin{array}{l}\text { Time-course measurements } \\
\text { (Fig 5A) }\end{array}$ & 6 & 6 & 2 \\
\hline Inhibition study (Fig 5B) & 7 & 7 & 1 \\
\hline pH dependence study (Fig 6) & 5 & 5 & 1 \\
\hline
\end{tabular}

Table 3: Number of required $2 \mathrm{~mL}$ microcentrifuge tubes for each sample type in the demonstrated studies.

2. Suspend the SAMB stock solution until homogeneity and transfer the amount of substrate to be analyzed in the reactions immediately into the sample vials. The recommended volume is $25-300 \mu \mathrm{L}$, but it is to be set according to the individual experimental design (Table 4).

NOTE: Check if all SAMBs have been measured in the bottom of the tubes. SAMBs may stick to the wall of the tube, which can distort the assay results. If different volumes are to be measured sequentially, start aliquoting with the highest volume and try to minimize the change of the pipettes and/or pipette tips.

\begin{tabular}{|l|c|c|c|}
\hline Study type & $\mathbf{R}$ & $\mathbf{B}$ & $\mathbf{C}$ \\
\hline $\begin{array}{l}\text { S-dependent } \\
\text { measurements (Fig 4) }\end{array}$ & $25-50-100-150-250$ & $25-50-100-150-250$ & 25 \\
\hline $\begin{array}{l}\text { Time-course measurements } \\
\text { (Fig 5A) }\end{array}$ & 25 & 25 & 25 \\
\hline Inhibition study (Fig 5B) & 120 & 120 & 120 \\
\hline $\begin{array}{l}\text { pH dependence study (Fig } \\
\text { () }\end{array}$ & 100 & 100 & 100 \\
\hline
\end{tabular}

Table 4: Volume of the SAMB solution measured in the sample vials of each sample type in the demonstrated studies.

3. Place the sample tubes containing the aliquoted SAMB suspension into the MPC and slightly move the MPC back and forth.

4. Carefully remove the supernatant from the SAMBs and discard it. 
5. Remove the tubes from the MPC and add the calculated volume of reaction buffer (cleavage or elution buffer [100 mM EDTA, $0.05 \%$ Tween $20, \mathrm{pH} 7]$ ) carefully to the SAMBs.

NOTE: Calculate the buffer volume according to the individual experimental design (Table 5). For $2 \mathrm{~mL}$ tubes, the recommended final volume of the reaction mixture (the volume of the reaction buffer to be added in this step + the volume of the solution to be added in step 4.2.3) is 50-150 $\mathrm{LL}$. Make sure that all of the SAMBs are washed in the added buffer. Elution buffer is used instead of cleavage buffer in the cases of substrate control (C) samples. For an inhibition study, the inhibitor of choice is recommended to be added at this step.

\begin{tabular}{|l|l|}
\hline Study type & Volume of the reaction buffer $(\boldsymbol{\mu L})$ \\
\hline S-dependent measurements (Fig 4) & $68 \mu \mathrm{L}$ cleavage buffer \\
\hline Time-course measurements (Fig 5A) & $68 \mu \mathrm{L}$ cleavage buffer \\
\hline Inhibition study (Fig 5B) & $\begin{array}{l}67.3 \mu \mathrm{L} \text { cleavage buffer }+0.7 \mu \mathrm{L} \text { inhibitor } \\
\text { stock solution* }\end{array}$ \\
\hline pH dependence study (Fig 6) & $69.5 \mu \mathrm{L}$ cleavage buffer ${ }^{\star *}$ \\
\hline
\end{tabular}

Table 5: Volume of reaction buffer in the demonstrated studies. *Amprenavir was solved in dimethyl-sulfoxide; amprenavir stock solutions (ranging from $1 \mathrm{nM}$ to $1 \mu \mathrm{M}$ concentrations) were applied for inhibitory study (see Figure $\mathbf{5 B}$ ). ${ }^{* \star} \mathrm{The} \mathrm{pH}$ of the applied cleavage buffer ranged from $\mathrm{pH}$ 6.0-8.5.

6. Close the lids of the tubes. Now the samples are ready for the assay.

NOTE: The samples can be stored at $4{ }^{\circ} \mathrm{C}$ for up to $24 \mathrm{~h}$, but the storage is only applicable if the SAMB stock solution was used immediately after the preparation (see step 4.1.3.2).

\section{Initiation of the proteolytic reactions}

1. Prepare the proteolytic enzyme solution according to the experimental needs.

NOTE: It is recommended to use a cleavage buffer to dissolve and/or dilute the enzyme. Protocols for the purification of HIV- $1^{14}$ and TEV PRs ${ }^{18}$ have been published previously.

2. Set the thermoshaker's agitation rate $(600 \mathrm{rpm})$ and incubation temperature (Table 6).

\begin{tabular}{|l|l|}
\hline Study type & Incubation temperature $\left({ }^{\circ} \mathrm{C}\right)$ \\
\hline S-dependent measurements (Fig 4) & 37 \\
\hline Time-course measurements (Fig 5A) & 37 \\
\hline Inhibition study (Fig 5B) & 37 \\
\hline pH dependence study (Fig 6) & 30 \\
\hline
\end{tabular}

Table 6: Incubation temperatures applied in different study types. For HIV-1 PR, $37^{\circ} \mathrm{C}$ is recommended, while $30^{\circ} \mathrm{C}$ is recommended for TEV PR.

3. Add the enzyme solution to the reaction samples for initializing proteolytic reactions.

NOTE: In the case of substrate blank (B) and C samples, add cleavage buffer (enzyme buffer) and elution buffer, respectively. The volume is to be calculated according to the individual experimental needs (Table 7). For $2 \mathrm{~mL}$ tubes, the recommended final volume of the reaction mixture (the volume of the reaction buffer added in step 4.1.4.5 + the volume of the solution to be added in this step) is $50-150 \mu \mathrm{L}$.

\begin{tabular}{|l|l|}
\hline Study type & \multicolumn{1}{|l|}{$\begin{array}{l}\text { Volume of the enzyme solution/enzyme buffer/ } \\
\text { elution buffer }(\boldsymbol{\mu L})\end{array}$} \\
\hline S-dependent measurements (Fig 4) & 2 \\
\hline Time-course measurements (Fig 5A) & 2 \\
\hline Inhibition study (Fig 5B) & 2 \\
\hline pH dependence study (Fig 6) & 0.5 \\
\hline
\end{tabular}

Table 7: Volume of the enzyme solution/enzyme buffer/elution buffer added during the initialization of the assay samples in the case of the demonstrated studies.

4. Stir up the beads carefully by gently moving the tubes, and place the tubes immediately into the already shaking thermoshaker. NOTE: Manual sample termination (see section 4.3) takes more time than the initiation; hence, a registered delay of at least 2 min is recommended between the reactions' initiations.

5. Incubate the samples according to the experimental design (Table 8).

\begin{tabular}{|l|l|}
\hline Study type & Incubation times (min) \\
\hline S-dependent measurements (Fig 4A) & 7 \\
\hline S-dependent measurements (Fig 4B) & 120 \\
\hline Time-course measurements (Fig 5A) & $0-2.5-5-10-15-20$ \\
\hline Inhibition study (Fig 5B) & 10 \\
\hline pH dependence study (Fig 6) & 60 \\
\hline
\end{tabular}


Table 8: Incubation times applied to the assay samples in the different measurements.

\section{Termination of the proteolytic reactions}

1. Take the sample out of the shaker, $30 \mathrm{~s}$ prior to the end of incubation, and spin it promptly.

2. Place the tube onto the MPC, let it stand for $15 \mathrm{~s}$, and slightly move the MPC back and forth.

3. Open the lid and transfer the supernatant carefully to a plate or a new tube.

NOTE: Do not touch the concentrated beads with the tip of the pipette. The collected supernatant of $C$ samples and $R$ samples with a high degree of cleavage may show visible fluorescence with or even without the using of a DRBT.

\section{Fluorescent detection}

1. Transfer $2 \times 30 \mu \mathrm{L}$ of the separated sample supernatants to a black half-area microplate.

2. Measure the fluorescence using the appropriate excitation and emission filters.

NOTE: Measure the basic fluorescence of the cleavage buffer and elution buffer, as well. Filter combinations need to be chosen based on the measured fluorescent protein (Table 9).

\begin{tabular}{|l|l|l|}
\hline Fluorescent protein & Excitation filters (nm) & Emission filters (nm) \\
\hline mTurqiouse2 & $355 / 40$ & $460 / 25$ \\
\hline mEYFP & $544 / 15$ & $590 / 10$ \\
\hline mApple & $544 / 15$ & $590 / 10$ \\
\hline
\end{tabular}

Table 9: Excitation and emission filters used to detect different fluorescent proteins.

5. Calibration

NOTE: To generate calibration curves in step 4.6.1, fluorescence intensity values of cleavage- or elution-buffer-solved purified substrates at different concentrations need to be measured.

1. Purify the fluorescent substrates.

NOTE: For purification, SAMBs of the substrate blank (B) samples after the protease assay may be collected, or a new SAMB suspension can also be prepared (see sections 4.1.1 and 4.1.2).

1. Place a tube with SAMBs suspended in $1 \mathrm{~mL}$ of cleavage buffer $(2 \%-10 \%$; v/v) to the MPC and collect the magnetic beads by turning the MPC upside-down in every direction.

2. Open the tube and remove the cleavage buffer, both from the tube and the lid.

3. Remove the tube from the MPC and add $400-600 \mu \mathrm{L}$ of elution buffer to the SAMBs.

4. Slowly rotate the closed tube with a rotator at room temperature for $5 \mathrm{~min}$.

5. Place the tube onto the MPC and collect the beads by turning the MPC upside-down.

6. Remove the supernatant containing the purified intact fluorescent substrate (eluate) and transfer it to a new low-protein-binding microcentrifuge tube.

NOTE: Eluate shows clearly visible fluorescence with or even without using a DRBT.

2. Perform parallel buffer exchange by using two $0.5 \mathrm{~mL} 10 \mathrm{~K}$ ultrafiltration devices.

1. Measure half volume of the prepared eluate $(200-300 \mu \mathrm{L})$ into each ultrafiltration device.

2. After at each centrifugation step, dilute the concentrated eluate in the first and the second ultrafiltration devices by elution buffer and cleavage buffer, respectively.

3. After the recovery, adjust the concentrated samples solved in the different buffers to the same volume, between $120-200 \mu \mathrm{L}$. NOTE: Now the protein content of the cleavage buffer-solved substrate is identical to the elution buffer-solved substrate; therefore, it is not necessary to determine the protein content of the latter one at step 4.5.3, if the method used for measuring protein concentration interferes with EDTA.

3. Determine the protein content of the substrates dissolved either in elution or cleavage buffer by measuring the absorbance at $280 \mathrm{~nm}$. NOTE: Other methods (e.g., Bradford or bicinchoninic acid (BCA) assays) may also be used to measure protein concentration, but possible interference with EDTA (present in the elution buffer) or with the absorbance of the fluorescent substrate needs to be considered. The initial protein content of the substrate solution to be applied in step 4.5.4 is recommended to be between 0.4-2.0 mg/ $\mathrm{mL}$ in order to generate a calibration curve in an appropriate range. See Table 10 for extinction coefficients.

\begin{tabular}{|c|c|c|}
\hline Substrate & $\begin{array}{l}\text { Molecular weight } \\
\text { (Da) }\end{array}$ & $\begin{array}{l}\text { Extinction coefficient } \\
\left(\mathrm{M}^{-1} \mathrm{~cm}^{-1} \text {, at } 280 \mathrm{~nm}\right. \\
\text { measured in water })\end{array}$ \\
\hline $\begin{array}{l}\mathrm{His}_{6}-\mathrm{MBP}-\mathrm{VSQNY} \mathrm{Y}^{*} \mathrm{PIVQ}- \\
\text { mTurquoise2 }\end{array}$ & 72101.7 & 96845 \\
\hline $\begin{array}{l}\text { His }_{6}-\mathrm{MBP}-\mathrm{KARVL}{ }^{*} \mathrm{AEAM}- \\
\text { mTurquoise2 }\end{array}$ & 72042.7 & 95355 \\
\hline $\begin{array}{l}\text { His }_{6}-M B P-V S Q N Y^{*} \text { PIVQ- } \\
\text { mEYFP }\end{array}$ & 72367.1 & 94325 \\
\hline $\begin{array}{l}\mathrm{His}_{6}-\mathrm{MBP}-\mathrm{VSQNY}{ }^{*} \mathrm{PIVQ}- \\
\text { mApple }\end{array}$ & 72145.9 & 105200 \\
\hline
\end{tabular}

Table 10: Molecular weights and the extinction coefficients of the different recombinant fluorescent fusion protein substrates.

4. Prepare a twofold serial dilution in at least eight steps, both from the elution- and from the cleavage-buffer-solved substrate solutions, using elution or cleavage buffer for the dilution, respectively. 
5. Transfer $30 \mu \mathrm{L}$ of each dilution point to a black half-area microplate.

6. Measure the fluorescence with a fluorimeter, using the setting applied in step 4.4.2.

NOTE: Measure the basic fluorescence of both the cleavage and the elution buffer.

\section{Evaluation of the assay}

1. Plot the calibration curves.

1. Calculate the concentration (in $\mathrm{mM}$ ) of the purified substrate solutions (used in step 4.5.4), based on the protein content determined in step 4.5.3.

2. Correct the relative fluorescence intensity values (RFU) of the serial dilution points by the basic RFU values of the applied dilution buffer (the cleavage buffer or the elution buffer).

3. Plot the corrected RFU values against the molar concentration of the cleavage- or elution-buffer-solved purified substrates and perform a linear regression (force the intercept to zero).

NOTE: A high $\mathrm{R}^{2}$ value $(>0.97)$ indicates a good linear correlation between the fluorescence and the concentration of the fluorescent protein. In this case, the slope of the regression line can be used to assess the concentration of the assay components in the examined range in steps 4.6.2 and 4.6.3. Experimental errors and data point distribution may affect the reliability of the calibration; thus, a graphical evaluation may be performed with the help of zoom-in graphs (as shown in Figure 3 ), in order to check whether $R^{2}$ and the slope values are influenced by the data.

2. Calculate the amount of $\mathrm{C}$-terminal fluorescent cleavage product in the reaction samples.

1. Correct the RFU values of each R sample with the RFU values of the corresponding $B$ sample.

2. Calculate the cleavage product concentration (in $\mathrm{mM}$ ) in the reaction samples by dividing the corrected RFU values by the slope of the cleavage-buffer-based calibration curve (see step 4.6.1.3).

3. Calculate the applied substrate concentration in the reaction samples.

1. Correct the RFU values of the $\mathrm{C}$ sample with the RFU value of the basic elution buffer.

2. Calculate the concentration of the eluted substrate (in $\mathrm{mM}$ ) in the supernatants of the $\mathrm{C}$ sample by dividing their corrected RFU values by the slope of the elution-buffer-based calibration curve (see step 4.6.1.3).

3. Determine the substrate concentration (in $\mathrm{mM}$ ) of the SAMB stock solution used for creating the assay samples in step 4.1.4.2, based on the following equation:

$\mathrm{c}_{S A M B}(\mathrm{mM})=\frac{c_{C}(m M) \times V_{r}(\mu L)}{V_{S A M B}(\mu L)}$

Here, $c_{S A M B}$ is the molar concentration of the SAMB stock solution prepared at section $4.1 .3 ; c_{C}$ is the molar concentration of the eluted substrate in the $C$ sample calculated at step 4.6.3.3; $V_{r}$ is the volume of the reaction mixture created by the addition of the reaction buffer in step 4.1.4.5 and the enzyme buffer in step 4.2.3.; and $V_{S A M B}$ is the volume of the SAMB stock solution in the $C$ sample (step 4.1.4.2).

4. Calculate the molar concentration of the substrates in each $\mathrm{R}$ sample based on the molar concentration of the SAMB stock solution (in $\mathrm{mM}$ ) according to the volume (in $\mu \mathrm{L}$ ) measured in each reaction sample tube at step 4.1.4.2.

4. Perform data processing.

NOTE: The data analysis depends on the aim of the experiment. The video shows an example for data processing of a substratedependent kinetic study on HIV-1 PR using $\mathrm{His}_{6}-\mathrm{MBP}$-VSQNY*PIVQ-mTurquoise2 substrate. The initial velocity values are calculated from the number of $\mathrm{C}$-terminal cleavage fragments and are plotted against the applied substrate concentration. The kinetic parameters are determined by a Michaelis-Menten nonlinear regression analysis.

\section{Recycling of the magnetic beads}

NOTE: After performing an assay, the magnetic agarose beads can be collected and recycled.

1. Collect the used magnetic beads with the MPC and discard the supernatant.

1. Wash the beads with $1.8 \mathrm{~mL}$ of the following buffers, in the order given: regeneration buffer $\mathrm{A}(0.05 \%$ Tween $20,0.5 \mathrm{M} \mathrm{NaOH})$, regeneration buffer $B(0.05 \%$ Tween 20$)$, regeneration buffer $C(0.05 \%$ Tween $20,100 \mathrm{mM}$ EDTA, pH 8$)$, regeneration buffer $B$, regeneration buffer $\mathrm{D}\left(0.05 \%\right.$ Tween $20,100 \mathrm{mM} \mathrm{NiSO}_{4}, \mathrm{pH}$ 8), regeneration buffer $\mathrm{B}$, and regeneration buffer $\mathrm{E}(0.5 \%$ Tween $20,30 \%$ ethanol, $\mathrm{pH} 7$ ).

NOTE: For the washing procedure, see step 4.1.1.4.

2. Store the recycled beads in regeneration buffer $\mathrm{E}$ at $4{ }^{\circ} \mathrm{C}$.

\section{PAGE analysis}

\section{Sample preparation}

NOTE: After performing the Ni-NTA magnetic-bead-based assay, the assay supernatants can be analyzed by PAGE. In this case, skip steps 5.1.1 and 5.1.2. However, it is also possible to analyze the purified fluorescent substrates solution and/or their cleavage fragments after insolution digestion with the protease of interest. In this case, continue the protocol with step 5.1.1.

1. Prepare the purified fluorescent substrate solution according to step 4.5.1.

2. Perform in-solution digestion.

1. Exchange elution buffer with cleavage buffer in the $0.5 \mathrm{~mL} 10 \mathrm{~K}$ ultrafiltration device and aliquot the samples to be digested into $1.5 \mathrm{~mL}$ microcentrifuge tubes.

NOTE: For the PAGE analysis, we aliquoted $68 \mu \mathrm{L}$ of each substrate, but the number of sample tubes and the volume of substrate solution to be aliquoted can be optimized according to the individual experimental design.

2. Add the enzyme solution to the samples. 
NOTE: For the PAGE analysis, we applied $2 \mu \mathrm{L}$ of HIV-1 PR, prepared as described by Bozóki et al. ${ }^{14}$, but the volume may be optimized according to the individual experimental design. It is recommended to use cleavage buffer to dissolve and/or dilute the enzyme.

3. Incubate the samples according to the experimental design.

NOTE: For the PAGE analysis, we incubated the reaction mixture for $45 \mathrm{~min}$ at $37^{\circ} \mathrm{C}$, but the incubation time and temperature need to be set according to the experimental design.

4. Terminate the reaction by performing step 5.1.3.

3. Prepare the sample for PAGE.

NOTE: The fluorescent-substrate-containing samples may be prepared for the PAGE by a nondenaturing or by a denaturing method. For the use of nondenaturing or denaturing conditions, follow step 5.1.3.1 or 5.1.3.2, respectively.

1. Prepare a nondenatured sample: $\mathrm{mix} 30 \mu \mathrm{L}$ of the sample with $6 \mu \mathrm{L}$ of $6 \mathrm{x}$ nondenaturing sample-loading buffer ( $300 \mathrm{mM}$ Tris, $20 \%$ glycerol, $0.05 \%$ bromophenol blue, $\mathrm{pH} 6.8$ )

2. Prepare a denatured sample: $\mathrm{mix} 30 \mu \mathrm{L}$ of the sample with $6 \mu \mathrm{L}$ of $6 \mathrm{x}$ denaturing sample-loading buffer $(300 \mathrm{mM}$ Tris, $20 \%$ glycerol, $0.05 \%$ bromophenol blue, $12 \%$ SDS, $100 \mathrm{mM} \beta$-mercaptoethanol, $\mathrm{pH}$ 6.8), and heat the samples at $95^{\circ} \mathrm{C}$ for $10 \mathrm{~min}$.

\section{SDS-PAGE analysis}

NOTE: Optionally, if only nondenatured (prepared in step 5.1.3.1) samples are to be analyzed, a native PAGE can also be performed. In this case, skip section 5.3 .

1. Prepare an SDS-polyacrylamide gel (use $14 \%$ separating and $4 \%$ stacking gel) and fill the tank with electrophoresis buffer (2.5 $\mathrm{mM}$ Tris, $19.2 \mathrm{mM}$ glycine, $0.01 \%$ SDS).

2. Add the samples (prepared in step 5.1.3.1 or 5.1.3.2) to the wells of a polyacrylamide gel and perform electrophoresis at $120 \mathrm{~V}$ voltage

3. Remove the gel cassette from the running module and place the gel into a washing tank.

NOTE: Nondenatured samples are already visible in the gel, even by the naked eye or with a DRBT.

3. In-gel renaturation and detection of fluorescent proteins

NOTE: To detect the fluorescent proteins in denatured samples (prepared in step 5.1.3.2) on the DRBT, SDS needs to be washed out from the gel, to partially renature the proteins.

1. Add $\sim 100 \mathrm{~mL}$ of distilled water to the gel and rinse the gel at least for $30 \mathrm{~min}$.

NOTE: To improve the SDS removal, replace the water every $10 \mathrm{~min}$, or rinse up to $60 \mathrm{~min}$.

2. Visualize the fluorescent proteins by using a DRBT, or by UV imaging.

\section{Conventional Coomassie staining of the gel}

1. Stain the gel with Coomassie Brilliant Blue dye to visualize nonfluorescent proteins.

\section{Representative Results}

Figure 1A shows the schematic structure of a representative fluorescent recombinant protein substrate which can be processed by HIV-1 PR at its specific cleavage site sequence. Figure 1B represents the substrate production and their possible applications in protease assays, including Ni-NTA magnetic-bead-based assay and/or PAGE.

To obtain reliable data by fluorimetry, a calibration procedure is required, in order to determine the quantities of fluorescent substrates and cleavage products. For this, the fluorescence intensity values of the different substrates in the different buffer conditions need to be measured and need to be correlated to their concentrations in the assayed concentration range (Figure 3). The slope values of the calibration curves can be applied to determine the amounts of substrates and cleavage products in the assay samples. The slopes of the calibration curves are independent of the cleavage site sequences inserted into the substrates (Table 11) and can potentially be used for a series of substrates fused to the same type of fluorescent protein. Zoom-in graphs are shown for all linear regressions, to enlarge the lower concentration ranges as well (Figure 3). It is important to note that the calibration needs to be performed carefully because a proper distribution of data points is required for a reliable calibration. For this reason, twofold serial dilution is applied to prepare the samples for calibration, because the $R^{2}$ value indicates a good correlation between the concentration of fluorescent protein and fluorescence only if a sufficient number of data points have been used to cover the entire concentration range. Furthermore, experimental errors can highly affect the accuracy of the calibration; thus, a graphical evaluation of the regression lines may be also necessary.

A variety of enzymatic measurements can be performed by the protease assay, including an examination of the effect of the substrate concentration on reaction velocity (Figure 4A). By nonlinear regression, the data can be used to determine enzyme kinetic parameters (e.g., $v_{\text {max }}$ and $K_{m}$ ). An insufficient bead suspension and dispersion and an improper reaction termination may cause suboptimal results (Figure 4B), which are not suitable for calculating reliable enzyme kinetic values.

A dependence of the product formation on time can be determined by the assay (Figure 5A) (e.g., during the optimization of the cleavage reaction parameters). Enzyme activity in the presence of an inhibitor can also be investigated (Figure 5B) for the determination of the active enzyme concentration and inhibitory constant. Using the same methodology, effects of other inhibitors can also be screened by the assay.

The protease assay is useful when investigating the effects of $\mathrm{pH}$ on enzyme activity, as well. Figure $6 \mathbf{A}$ represents the dependence of enzyme activity on $\mathrm{pH}$ by the example of TEV PR, which has a wide optimal $\mathrm{pH}$ range $(\mathrm{pH}$ 6-9). If the $\mathrm{pH}$ dependence of enzyme activity is studied (or enzymes having an acidic $\mathrm{pH}$ optimum need to be measured), it is necessary to consider that the affinity binding of recombinant substrates to the beads may be restricted at slightly acidic $\mathrm{pH}$. An elevated dissociation of the substrates from the beads (Figure 6B) may cause a distortion of the assay results. In order to consider the spontaneous substrate dissociation from the beads, the values measured for reaction samples need to be corrected by those of B samples. 
Figure 7 shows that the nondenatured fluorescent proteins can be differentiated in the gel based on their colors, using blue light transillumination (Figure 7A). If the determination of the molecular weights of substrates/cleavage fragments is necessary, denaturing conditions can also be used for sample preparation, because fluorescent proteins can be partially renatured in the gel, and can be detected by UV illumination (Figure 7B) or by Coomassie staining (Figure 7C). If the R samples are analyzed, only the C-terminal cleavage products are visible (Figure 7C), while the $\mathrm{N}$-terminal cleavage fragments and the uncleaved substrates remain attached to the beads. Occasionally, proteins may be partially denatured despite using nondenaturing conditions (Figure 7C), and while the nondenatured proteins are more abundant, denatured forms are also detectable in the sample. This phenomenon does not influence the detection of proteolytic cleavage but needs to be considered in the case of quantitative densitometry of nondenatured samples.

Although the detailed description is shown only for a $2 \mathrm{~mL}$-tube-based assay, the assay can be adapted for a 96-well plate-based system (Figure 8), which has already been tested successfully in our laboratory (not shown). The 96-well plate-adapted format is fully compatible with the fluorimetric and electrophoretic analyses, as well, and the obtained data can also be evaluated based on the methods described in this paper

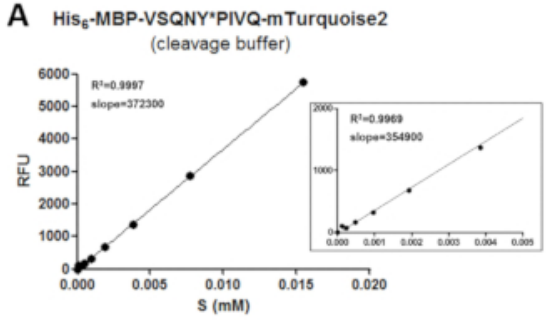

B

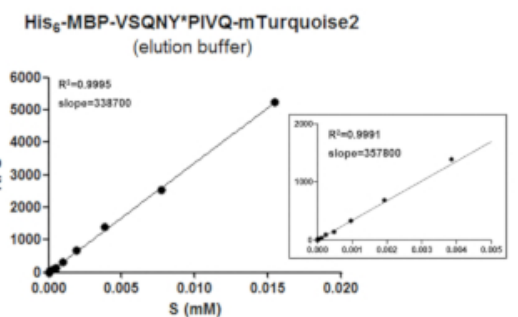

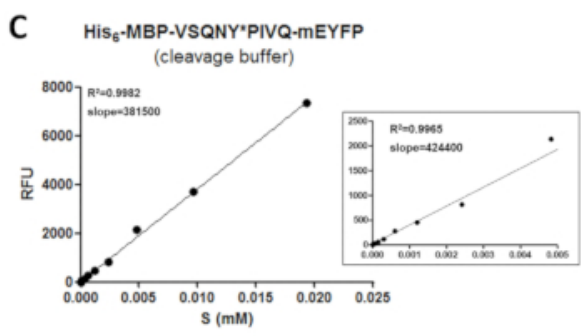

D

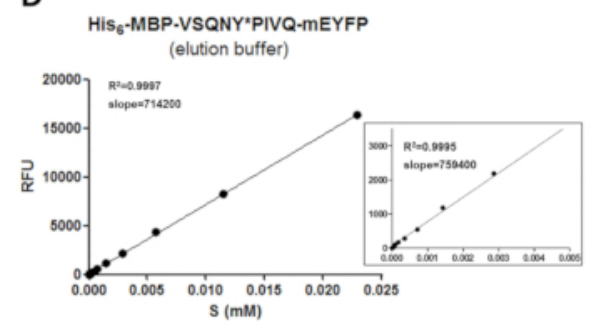

Figure 3: Calibration curves. Representative substrate calibration curves are demonstrated with the example of two recombinant substrates fused to different C-terminal fluorescent tags: (A and B) $\mathrm{His}_{6}-\mathrm{MBP}-\mathrm{VSQNY}{ }^{*} \mathrm{PIVQ}-\mathrm{mT}$ Trquoise2 and (C and $\left.\mathbf{D}\right) \mathrm{His}_{6}-\mathrm{MBP}-\mathrm{VSQNY}{ }^{*} \mathrm{PIVQ}-\mathrm{mEYFP}$. Zoom-in figures are also shown to represent the linear regression of data points in the $0-0.005 \mathrm{mM}$ substrate concentration range. Please click here to view a larger version of this figure.

A

His $_{6}$-MBP-VSQNY*PIVQ-mApple

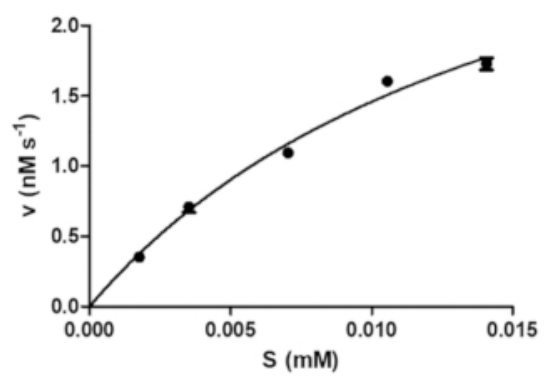

B

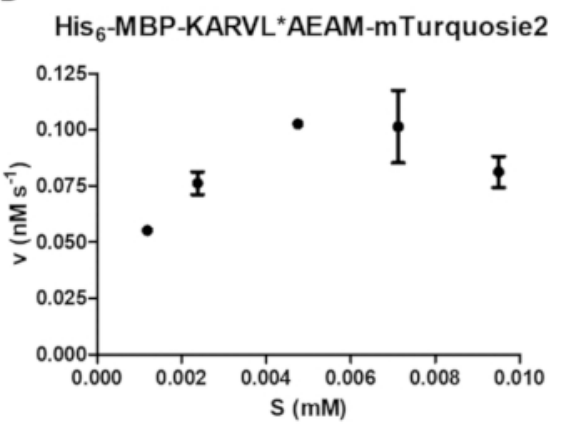

Figure 4: Determination of enzyme kinetic parameters. Substrate-dependent kinetic measurements were performed by HIV-1 PR (at a final active concentration of $41.2 \mathrm{nM}$ ). The initial velocity values were plotted against the substrate concentration and a Michaelis-Menten nonlinear regression analysis was performed. The error bars represent $\mathrm{SD}(n=2)$. (A) A representative optimal result is shown with the example of His ${ }_{6}^{-}$ MBP-VSQNY*PIVQ-mApple fusion protein substrate. (B) A representative suboptimal result is also shown for the His ${ }_{6}-\mathrm{MBP} \mathrm{KARVL}{ }^{*} \mathrm{AEAM}-$

mTurquoise2 substrate, where the setting of proper substrate concentrations was problematic due to an insufficient homogenization of the SAMB stock solution, while relatively high errors were caused by improper reaction termination. Please click here to view a larger version of this figure. 

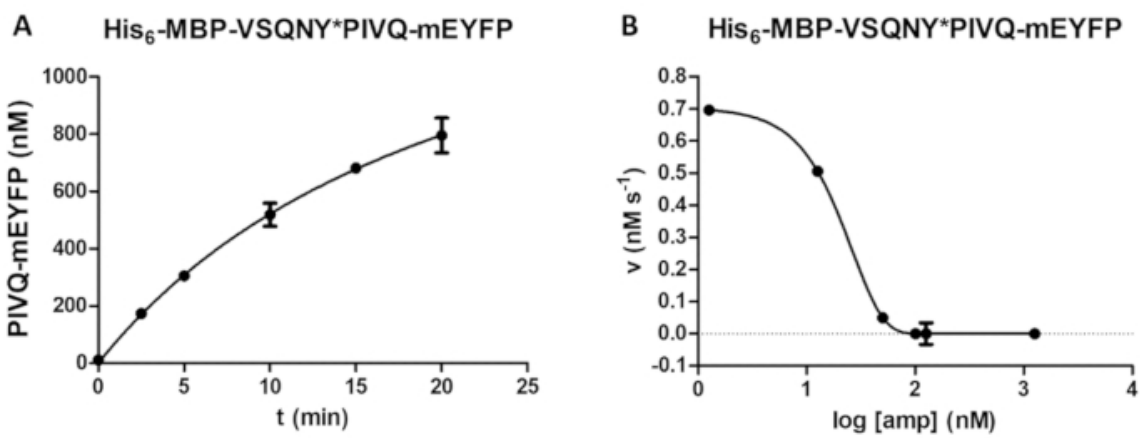

Figure 5: Time-course and inhibitory study. (A)His ${ }_{6}-M B P-V S Q N{ }^{*} P I V Q-m E Y F P$ recombinant fusion protein substrate (at a final concentration of $0.00326 \mathrm{mM}$ ) was cleaved by HIV-1 PR (at a final active concentration of $41.2 \mathrm{nM}$ ), and the release of fluorescent PIVQ-mEYFP proteolytic fragments was measured to perform a time-course analysis. The measurements were carried out at five different time points. The error bars represent SD $(n=2)$. (B) His - MBP-VSQNY*PIVQ-mEYFP was used as substrate (at $0.0015 \mathrm{mM})$ to determine the inhibitory effect of amprenavir on the activity of HIV-1 PR (at a total concentration of $163.8 \mathrm{nM}$ ). By plotting the data, the half maximal inhibitory concentration (IC50) could be assessed and the active enzyme concentration (a final active concentration of $41.2 \mathrm{nM}$ ) of the applied HIV-1 PR could also be calculated based on the inhibition curve. The error bars represent SD $(n=3)$. Please click here to view a larger version of this figure.
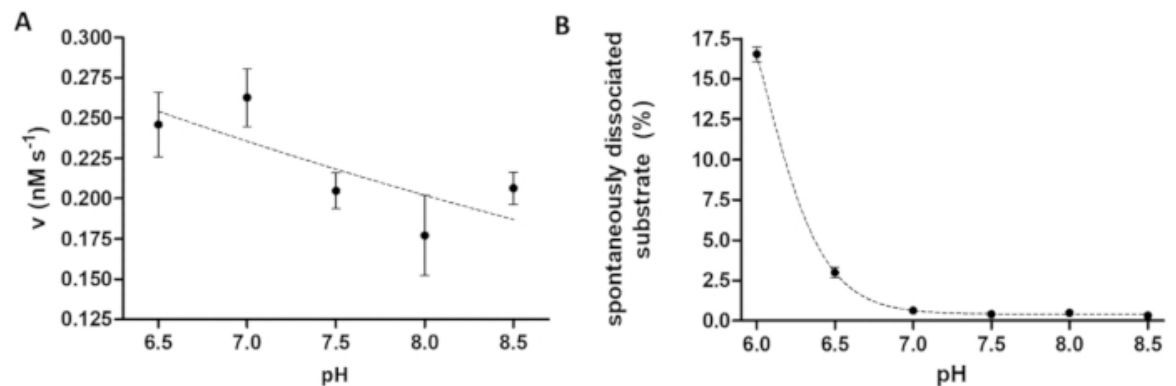

Figure 6: Studying dependence of enzyme activity and spontaneous substrate dissociation on pH. (A) The His ${ }_{6}-M B P-V S Q N Y^{*} P I V Q-$ mTurquoise2 substrate (in $0.033 \mathrm{mM}$ ) was used to measure the enzyme activity of TEV PR (at a final total concentration of $91.42 \mathrm{nM}$ ) in cleavage buffer set to a different $\mathrm{pH}$, between the range of 6.5-8.5. The error bars represent $\mathrm{SD}(n=2)$. The plotted data has been published previously ${ }^{14}$. (B) Based on the relative fluorescent intensity values of the substrate blank samples, the spontaneous dissociation of the His $6^{-}$ MBP-VSQNY*PIVQ-mTurquoise2 substrate $(0.033 \mathrm{mM})$ from the magnetic beads was studied by using cleavage buffer with a different $\mathrm{pH}$, between 6.0-8.5. The plotted data has been published previously ${ }^{14}$. Please click here to view a larger version of this figure. 
A Detection by blue light transillumination

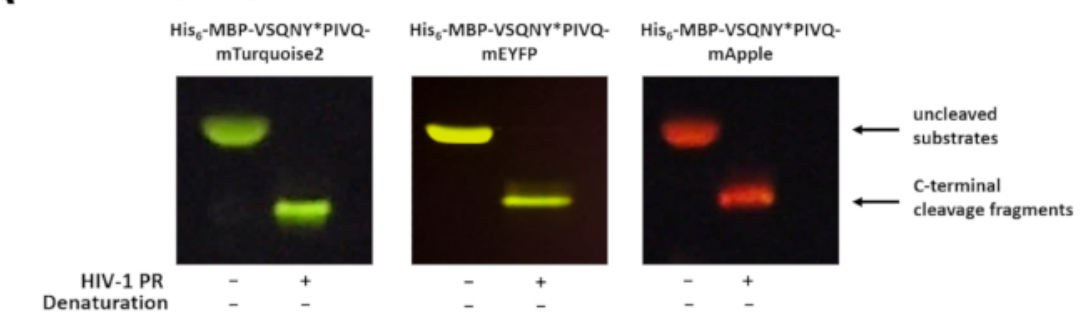

B Detection by UV illumination

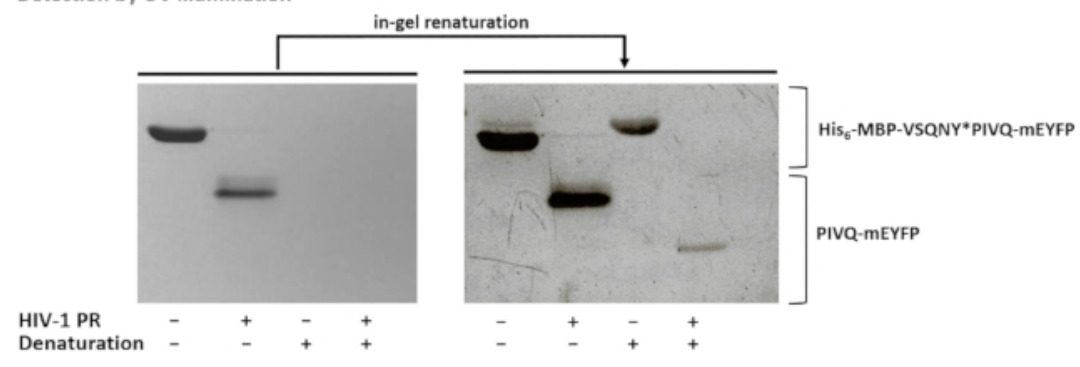

C Detection by Coomassie staining

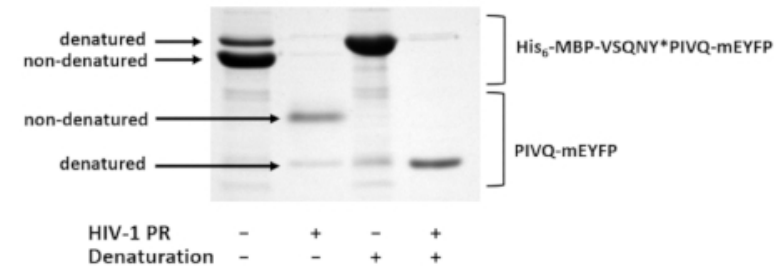

Figure 7: Detecting proteins in the gel by different methods. (A) Uncleaved and HIV-1 PR-digested fusion protein substrates after nondenaturing sample preparation were visualized by blue light transillumination after SDS-PAGE. The cleavage reaction was performed by insolution digestion. (B) Immediately after the PAGE, only nondenatured proteins could be detected in the gel by UV illumination, while after the removal of SDS, the previously denatured fluorescent proteins became partially renatured and detectable. The samples were prepared from the supernatants of the Ni-NTA magnetic-bead-based assay. (C) Coomassie staining can also be used for protein detection, after the in-gel renaturation. The SDS-present in the gel-may cause the partial denaturation of the native protein, but in native samples, the nondenatured forms are more abundant. The samples were prepared from the supernatants of the Ni-NTA magnetic-bead-based assay. Please click here to view a larger version of this figure. 
A

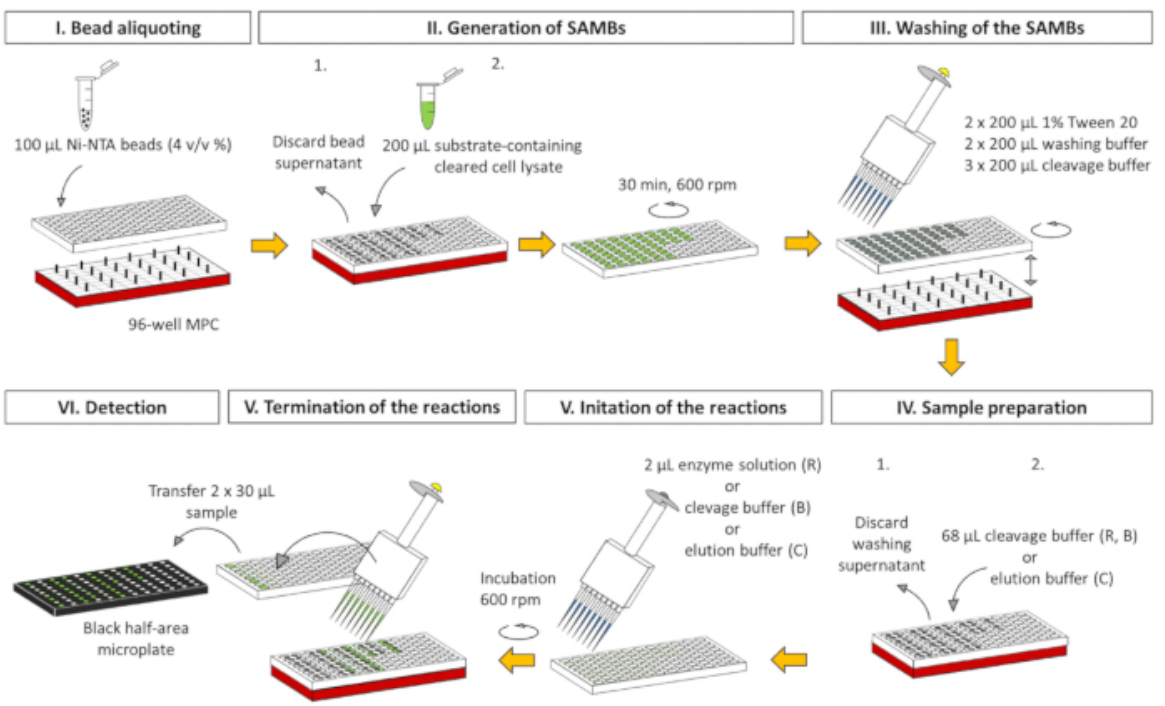

B

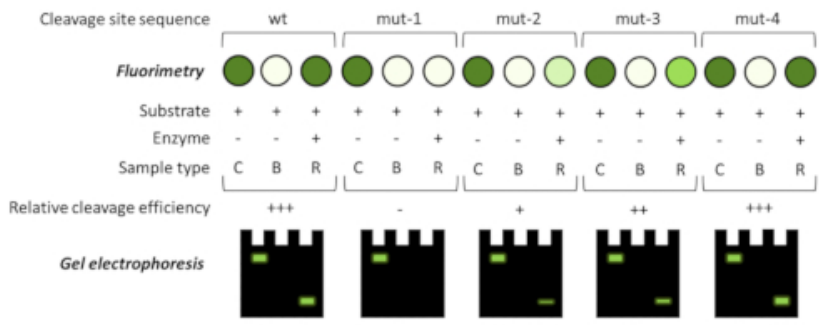

Figure 8: 96-well plate-based adaptation of the assay platform. (A) The assay can be performed not only in $2 \mathrm{~mL}$ tubes but in the wells of a 96-well plate, as well. Here we show the schematic representation for the application of the assay to study the specificity of a fictitious protease by using a series of fluorescent substrates, which may contain wild-type (wt) or mutated (mut-1 to mut-4) cleavage site sequences. For handling the magnetic beads, a 96-well compatible magnetic particle concentrator (MPC) is to be used in the experiments. All the indicated volumes are related to a single well. To compare the cleavage efficiency of the different substrates, substrate conversion can be assessed from the percentage of substrate-blank-corrected RFU values of the reaction samples, considering the substrate-blank-corrected RFU values of the related substrate control samples as 100. (B) After fluorimetry, the separated supernatants of the assay samples can also be analyzed by PAGE, and the fluorescent protein components can be analyzed directly or after in-gel renaturation in case of nondenaturing and denaturing sample preparation, respectively. The three different assay sample types are also illustrated in each figure: $\mathrm{C}=$ substrate control, $\mathrm{B}=$ substrate blank, and $\mathrm{R}=$ reaction. Substrate control samples are in elution buffer, while the substrate blank and the reaction samples are in cleavage buffer. Please click here to view a larger version of this figure.

\begin{tabular}{|l|l|l|}
\hline Buffer & Fluorescent protein & CV\% of slopes (\%) \\
\hline Elution & mTurquoise2 & 6.04 \\
\cline { 1 - 1 } Cleavage & & 9.11 \\
\hline Elution & mApple & 10.92 \\
\cline { 1 - 1 } Cleavage & & 12.68 \\
\hline
\end{tabular}

Table 11: Coefficient of variance (CV\%) values of the slopes of the substrate calibration curves. To test whether the fluorescence of the recombinant protein substrates is dependent on the inserted cleavage site, calibrations were performed by series of mApple- and mTurquoise2fused substrates (six variants for each, containing different cleavage site sequences of HIV-1 protease), both in elution and cleavage buffers. We found that $\mathrm{CV} \%$ values of the slopes are under $15 \%$ in all cases, which implies that a single substrate calibration can be utilized for the evaluation of the different measurements performed by substrate variants containing the same fluorescent tag.

\section{Discussion}

Due to the intensive industrial and academic investigations of proteolytic enzymes and the constant demand for expeditious and affordable HTScompatible protease assay platforms accordingly, we have developed a magnetic-bead-based fluorescent protease assay. The assay is based on the use of recombinant fusion proteins which can be novel alternatives to the widely utilized synthetic peptide substrates.

In the developed assay format, the fusion protein substrates are immobilized to the surfaces of Ni-chelate-coated magnetic agarose beads. The substrate attachment is provided by the $\mathrm{N}$-terminal $\mathrm{His}_{6}$ affinity tag of the fusion protein, which is directly fused to an MBP tag in order to facilitate the folding and enhance the water solubility of the substrate ${ }^{13}$. The MBP is followed by cleavage sites of TEV PR and a protease of interest. The 
former may serve as a control cleavage site in the assay, while the latter can be processed by the protease to be investigated. The cleavage site is interchangeable; a short dsDNA sequence coding for the cleavage site of interest can be inserted into the flexible 'cloning cassette' of the expression plasmid by ligation. The recombinant fusion proteins contain a highly stable, monomeric fluorescent protein tag at the $\mathrm{C}$-terminal, which enables the endpoint detection of the enzyme-liberated, fluorescent C-terminal cleavage products released upon proteolytic cleavage (Figure 1A). The purified fluorescent intact substrates solved in different buffers are also used for calibration to assess the molar concentrations of substrates and cleavage products. In addition, after fluorimetry, the assay components can be analyzed by SDS-PAGE, as well. Both native (nondenatured) and denatured fluorescent proteins can be visualized in the gel, immediately after the electrophoresis or after subsequent in-gel renaturation, respectively. This additional procedure-in combination with a conventional Coomassie Brilliant Blue staining-may be used efficiently for the verification of the assay results (Figure 1B).

The assay procedure consists of simple, easy-to-execute steps in a low-volume format that may be fully adapted to a high-throughput automatic environment. However, independently from performing the assay either manually or with an automation system, the following parts of the assay are considered to be crucial and need special attention while performing the procedure. i) Homogeneity of the magnetic bead solution. A homogeneous magnetic bead solution must be used throughout the assay, both in purification and washing steps. Particularly, the reliability of protease assays strongly depends on properly aliquoting the substrate-attached magnetic bead (SAMB) stock solutions. In order to increase the effectiveness of the suspension and dispersion, it is recommended to set the bead concentration between $2 \%$ and $10 \%$ ( $\mathrm{v} / \mathrm{v}$ ). During sample preparation, the use of buffers supplemented with nonionic detergent (such as Triton X-100 or Tween 20) up to $2 \%$ may also decrease the adherence of the magnetic beads to plastic surfaces. The adherence of the beads to the walls of sample vials can be avoided if the bead suspensions are applied carefully to the bottoms of the vials instead of onto the walls of sample tubes. The homogeneity of the magnetic beads during the enzymatic reaction is also critical and can be ensured by continuously shaking the samples at $600 \mathrm{rpm}$ during incubation. Beads are properly dispersed in rounded or flat-bottomed plastic wares, while the use of V-bottom vials is not recommended. A suboptimal result caused by improper bead homogenization is represented in Figure 4B. ii) Termination of reaction samples. Another advantage of the method is that the enzymatic reaction can be terminated without the use of heat denaturation treatment or any potentially interfering chemical agents ${ }^{15}$. The termination can be carried out simply by separating the magnetic beads from the reaction mixture, using a conventional magnetic particle concentrator. While the removed reaction buffer contains the active enzyme and the generated C-terminal fluorescent cleavage products, the uncleaved substrates remain attached to the beads. Due to the presence of the active enzyme in the reaction buffer, the separation procedure needs to be performed carefully for reliable endpoint detection. Before placing the sample vials into the concentrator, it is recommended to apply a short spin centrifugation. After placing the tubes into the concentrator, provide at least $15 \mathrm{~s}$ for the beads to be collected. Slight movement of the separator back-and-forth may facilitate the collection of the beads. Please consider that, during a manually performed separation, the termination usually takes more time than the initiation of the reactions. Therefore, an approximately 2 min registered delay is recommended between the initiations if the same incubation time needs to be applied to all samples.

The principle of the described proteolytic assay is relatively simple; however, the versatility of the system is guaranteed by the flexible and stable substrate structure. The individual optimization of the assay may be limited only by the compatibility of the affinity beads with the applied conditions, reagents, and additives. In agreement with the manufacturer's protocol, we also found that the affinity binding of substrates to the NiNTA bead surfaces substantially weakens at $\mathrm{pH} \leq 6.5^{15}$. Therefore, it is recommended to apply substrate blank samples parallel to the reaction samples, and the rate of spontaneous substrate dissociation needs to be considered during the evaluation of results.

In those cases, where magnetic-bead-based assays cannot be performed due to the use of bead-incompatible components or a low $\mathrm{pH}$, in-solution digestion of the purified recombinant substrates can be also applied. In these cases, the reaction mixtures can be analyzed by electrophoresis, and the proteins can be visualized in the gel based on the described protocol. To investigate proteolytic activity, in-solution digestion and in-gel detection of the proteins may also be alternative tools of fluorimetry. A novelty of the designed substrate system is the application of an in-gel renaturation step after denaturing SDS-PAGE. While native (nondenatured) fluorescent proteins retain their fluorescence during electrophoresis, the fluorescent property is abolished upon denaturation (Figure 7B). However, the fluorescence of denatured proteins can be partially recovered by the removal of SDS from the gel. Thus, a separation of reaction components using denaturing conditions makes not only the fluorescence-based but the molecular-weight-based identification possible. Another advantage of the fluorescent in-gel detection compared to the analysis of a Coomassie-stained gel is that the (native or renatured) fluorescent proteins can be easily identified in the gel based on their fluorescence (see Figure 7). This may be important if cleavage reactions are performed in samples containing nonfluorescent contaminants or proteins highly resembling the molecular weights of each other.

Protease assays using similarly designed substrates have already been published previously ${ }^{8,9,10}$, and although the cleavage site of interest in those cases was also located between an affinity tag and a fluorescent protein, the assay system presented here not only repeats the described ideas but combines the different advantages of the previous platforms and also completes them with further improvements: i) the utilization of an MBP fusion partner, ii) the presence of a TEV PR control cleavage site, iii) the use of newly engineered monomeric FPs, and iv) the application of a unique substrate calibration procedure. The assay itself was particularly designed to be useful for enzyme specificity and kinetic studies in a safe, time- and cost-efficient manner, without the need for expensive instrumentation. The method is aimed to be a suitable and affordable tool for both industrial and academic research purposes. Due to the flexibility of the 'cloning cassette' of the expression plasmid, the system may be suitable for the fast and inexpensive generation of recombinant substrate libraries. The herein described assay is a feasible tool for the implementation of substrate specificity, enzyme mutagenesis, and inhibition studies and, also, provide an alternative tool to perform enzyme kinetics. The assay platform (from bacterial cell disruption to the determination of the kinetic parameters) can be adapted to an HTSand automation-based environment and, potentially, may be applied in industrial protease inhibitor screening and/or antiviral drug development. In addition, the adaptation of the assay for competitive proteolysis is also in the future scope of our laboratory. In such a competitive assay, two different substrates-each containing a different cleavage site fused to a different C-terminal fluorescent tag-are intended to be used simultaneously in the same cleavage reaction to investigate the preference of the studied enzyme for the given target sequences. Furthermore, the use of a 96-well plate-adapted assay form (Figure 8) is also being optimized for mutation screening by using a series of substrates with modified cleavage site sequences in case of cysteine proteases. 


\section{Disclosures}

The authors have nothing to disclose.

\section{Acknowledgements}

This work was supported in part by the GINOP-2.3.2-15-2016-00044 "PHARMPROT teaming" project and, also, financed by the Higher Education Institutional Excellence Programme of the Ministry of Human Capacities in Hungary, within the framework of the Biotechnology thematic program of the University of Debrecen. The authors are grateful for the members of the Laboratory of Retroviral Biochemistry for their scientific help during the assay development and also for their patience during filming the assay (especially to Norbert Kassay, Krisztina Joóné Matúz, and Vanda Toldi, who are appearing in the background of the video). The authors would also like to say special thanks to Gedeon Richter Plc., especially to Dr. Zoltán Urbányi for allowing Beáta Bozóki's work in the Department of Biochemistry and Molecular Biology as a guest researcher. The authors would also like to extend their gratitude to György Zsadányi, Balázs Tögyi, Balázs Pöstényi, and Zoltán Király from the Multimedia and E-learning Technical Center of the University of Debrecen for the professional assistance in audio and video production.

\section{References}

1. Meldal, M. Smart Combinatorial Assays for the Determination of Protease Activity and Inhibition. Molecular Informatics. 24 (10), 1141-1148 (2005).

2. Rao, M.B., Tanksale, A.M., Ghatge, M.S., Deshpande, V.V. Molecular and biotechnological aspects of microbial proteases. Microbiology and Molecular Biology Reviews. 62 (3), 597-635 (1998).

3. Zhang, G. Protease assays. In The Assay Guidance Manual. Edited by Sittampalam, G.S. et al. Eli Lilly \& Company and the National Center for Advancing Translational Sciences. Bethesda, MD (2012).

4. Woelcke, J., Hassiepen, U. Fluorescence-based biochemical assay formats. In A Practical Guide to Assay Development and HighThroughput Screening in Drug Discovery. Edited by Chen, T. CRC Press. Boca Raton, FL (2010).

5. Richardson, P.L. The determination and use of optimized protease substrates in drug discovery and development. Current Pharmaceutical Design. 8 (28), 2559-2581 (2002).

6. Diamond, S.L. Methods for mapping protease specificity. Current Opinion in Chemical Biology. 11 (1), $46-51$ (2007).

7. Schilling, O., Overall, C.M. Proteome-derived, database-searchable peptide libraries for identifying protease cleavage sites. Nature Biotechnology. 26 (6), 685-694 (2008).

8. Askin, S.P., Morin, I., Schaeffer, P.M. Development of a protease activity assay using heat-sensitive Tus-GFP fusion protein substrates Analytical Biochemistry. 415 (2), 126-133 (2011).

9. Chaparro-Riggers, J.F., Breves, R., Michels, A., Maurer, K.H., Bornscheuer, U. A GFP based assay for the determination of hydrolytic activity and substrate specificity of subtilisins under washing conditions. Journal of Molecular Catalysis B: Enzymatic. 35, 74-77 (2005).

10. Patel, D., Frelinger, J., Goudsmit, J., Kim, B. In vitro assay for site-specific proteases using bead-attached GFP substrate. Biotechniques. 31 (5), 1194, 1196, 1198 passim (2001).

11. Branchini, B.R. et al. Sequential bioluminescence resonance energy transfer-fluorescence resonance energy transfer-based ratiometric protease assays with fusion proteins of firefly luciferase and red fluorescent protein. Analytical Biochemistry. 414 (2), $239-245$ (2011).

12. Zhou, C., Yan, Y., Fang, J., Cheng, B., Fan, J. A new fusion protein platform for quantitatively measuring activity of multiple proteases. Microbial Cell Factories. 13 (1), 44 (2014).

13. Fox, J.D., Waugh, D.S. Maltose-binding protein as a solubility enhancer. Methods in Molecular Biology. 205, 99-117 (2003).

14. Bozóki, B. et al. A recombinant fusion protein-based, fluorescent protease assay for high throughput-compatible substrate screening. Analytical Biochemistry. 540-541, 52-63 (2018).

15. Mótyán, J.A., Miczi, M., Bozóki, B., Tözsér, J. Data supporting Ni-NTA magnetic bead-based fluorescent protease assay using recombinant fusion protein substrates. Data in Brief. 18, 203-208 (2018).

16. Balleza, E., Kim, J.M., Cluzel, P. Systematic characterization of maturation time of fluorescent proteins in living cells. Nature Methods. 15, 4751 (2018).

17. Hebisch, E., Knebel, J., Landsberg, J., Frey, E., Leisner, M. High variation of fluorescence protein maturation times in closely related Escherichia coli strains. PLoS One. 8, e75991 (2013).

18. Kapust, R.B. et al. Tobacco etch virus protease: mechanism of autolysis and rational design of stable mutants with wild-type catalytic proficiency. Protein Engineering, Design and Selection. 14, 993-1000 (2001). 